\title{
Moderasi Persepsi Kegunaan dan Kemudahan Pembelajaran terhadap Pengaruh Minat Belajar pada Tingkat Pemahaman Akuntansi
}

\author{
Anak Agung Ngurah Agung Kresnandra ${ }^{1}$ \\ I Wayan Gde Wahyu Purna Anggara ${ }^{2}$ \\ 1,2Fakultas Ekonomi dan Bisnis Universitas Udayana, Indonesia \\ *Correspondences : ngurahagungkresnandra@unud.ac.id
}

\begin{abstract}
ABSTRAK
Penelitian ini bertujuan untuk mengetahui kemampuan moderasi dari persepsi kegunaan dan kemudahan media pembelajaran daring OASE Udayana terhadap pengaruh minat belajar mahasiswa akuntansi pada tingkat pemahaman akuntansinya. Data primer penelitian ini yaitu penyebaran kuesioner dengan metode purposive sampling data yang terkumpul terlebih dahulu diuji pemenuhan syarat asumsi klasik, kemudian dianalisis menggunakan teknik analisis regresi moderasi (MRA). Hasil dari penelitian ini yaitu Minat belajar secara statistik berpengaruh terhadap tingkat pemahaman akuntansi, persepsi kegunaan dari media pembelajaran daring tidak mampu memperkuat ataupun memperlemah pengaruh minat belajar terhadap tingkat pemahaman akuntansi dan Persepsi kemudahan memoderasi pengaruh minat belajar pada tingkat pemahaman akuntansi.
\end{abstract}

Kata Kunci: Minat Belajar; Persepsi Kegunaan; Persepsi Kemudahan; Tingkat Pemahaman Akuntansi.

\section{Perceptions of Usefulness and Ease of Learning Moderation on the Effect of Learning Interest at the Level of Accounting Comprehension}

\begin{abstract}
This study aims to determine the moderating ability of the perceived usefulness and convenience of online learning media at OASE Udayana on the influence of accounting students' learning interest on their level of accounting understanding. The primary data of this research is the distribution of questionnaires using purposive sampling method. The collected data is first tested for the fulfillment of the classical assumption requirements, then analyzed using the technique of moderated regression analysis (MRA). The results of this study are that interest in learning statistically affects the level of accounting understanding, perceptions of the usefulness of online learning media are not able to strengthen or weaken the influence of interest in learning on the level of accounting understanding and perceived ease of moderating the effect of interest in learning on the level of accounting understanding.
\end{abstract}

Keywords: Learning Interests; Perceptions of Usefulness; Perceptions of Ease; Level of Accounting Understanding.

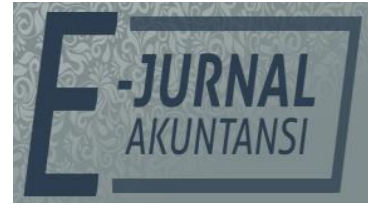

e-ISSN 2302-8556

Vol. 32 No. 1

Denpasar, Januari 2022

Hal. 93-108

DOI:

10.24843/EJA.2022.v32.i01.p07

PENGUTIPAN

Kresnandra, A. A. N. A. \&

Anggara, I W. G. W. P. (2022)

Moderasi Persepsi Kegunaan

dan Kemudahan

Pembelajaran terhadap Pengaruh Minat Belajar pada

Tingkat Pemahaman

Akuntansi. E-Jurnal Akuntansi, 32(1), 93-108

RIWAYAT ARTIKEL:

Artikel Masuk:

26 Desember 2020

Artikel Diterima: 25 Januari 2022

Artikel dapat diakses : https://ojs.unud.ac.id/index.php/Akuntansi/index 


\section{PENDAHULUAN}

Pendidikan akuntansi yang diselenggarakan di perguruan tinggi bertujuan untuk mendidik mahasiswa ketika lulus agar menjadi seorang akuntan professional yang memiliki tidak hanya cukup pengetahuan tetapi juga cakap dalam kemampuan di bidang akuntansi. Untuk dapat menghasilkan lulusan yang berkualitas maka perguruan tinggi harus terus meningkatkan kualitas pada sistem pendidikannya. (Horngren et al., 2011:88) mengkhawatirkan akan ketidakjelasan pada industri akuntansi yang dihasilkan oleh pendidikan tinggi akuntansi, hal ini dikarenakan banyak perguruan tinggi tidak mampu membuat anak didiknya menguasai dengan baik pengetahuan dan keterampilan hidup. Mahasiswa terbiasa dengan pola belajar menghafal tetapi tidak memahami. Tingkat pemahaman akuntansi mahasiswa dinyatakan dengan seberapa mengerti seorang mahasiswa terhadap apa yang sudah dipelajari yang dalam konteks ini mengacu pada mata kuliah akuntansi dan Indeks Prestasi Kumulatif (IPK). Tanda seorang mahasiswa memahami akuntansi tidak hanya ditujukan dari nilai-nilai yang didapatkannya dalam mata kuliah tetapi juga apabila mahasiswa tersebut mengerti dan dapat menguasai konsep-konsep yang terkait (Praptiningsih et al., 2009).

Akuntansi sebagai bahasa bisnis, sangat membantu dunia usaha dalam mengukur, mengkomunikasikan dan menginterprestasikan informasi aktifitas keuangan. Akuntansi banyak disalahartikan, sebagai bidang studi yang banyak menggunakan angka-angka untuk menghasilkan laporan keuangan. Kesalahan dalam pendekatan pengajaran akuntansi sering menyebabkan adanya persepsi dan pemahaman yang keliru tentang akuntansi. Padahal akuntansi tidak hanya memfokuskan pada masalah perhitungan semata, namun lebih pada penalaran yang membutuhkan logika berpikir (Budhiyanto et al., 2004). Untuk memiliki tingkat pemahaman akuntansi yang tinggi, beberapa faktor diduga memengaruhinya, salah satu di antaranya adalah faktor minat belajar.

Dalam memahami akuntansi adanya minat belajar merupakan hal yang penting juga untuk dipertimbangkan. Minat merupakan salah satu faktor internal yang dapat mempengaruhi prestasi belajar. Minat adalah kecenderungan yang tetap untuk memperhatikan dan mengenang beberapa kegiatan (Slameto, 2003:57). Menurut (Syah, 2003:151) minat adalah kecenderungan dan kegairahan yang tinggi atau keinginan yang besar terhadap sesuatu. Seorang mahasiswa yang menaruh minat besar terhadap mata kuliah akuntansi akan memusatkan perhatiannya lebih banyak dari mahasiswa lainnya. Kemudian, karena pemusatan perhatian yang intensif terhadap materi itulah yang memungkinkan mahasiswa tadi untuk belajar lebih giat dan akhirnya mencapai prestasi yang diinginkan.

Minat belajar tinggi yang dimiliki oleh mahasiswa akuntansi dalam mempelajari bidang ilmunya, tidak selalu berpengaruh linear terhadap tingginya tingkat pemahaman akuntansi mahasiswa tersebut. Hal ini dibuktikan dari beberapa hasil riset terdahulu yang masih inkonsisten. (Fanikmah \& Kurnia, 2016) menyebutkan di hasil penelitiannya bahwa minat belajar berpengaruh positif dan signifikan terhadap tingkat pemahaman akuntansi. Hasil ini juga ditemukan pada penelitian lainnya yaitu (Susanti et al., 2017), (Rokhana \& Sutrisno, 2016), dan (Atmaja et al., 2017). Berbeda dengan tiga peneliti sebelumnya penelitian (Adeviana, 2018) menemukan hasil bahwa minat belajar berpengaruh negatif 
terhadap tingkat pemahaman siswa. Hasil riset terbaru dari (Adeviana, 2018) juga mendukung hasil riset sebelumnya yang dilakukan (Minarni et al., 2014), yang menemukan bahwa minat belajar memiliki pengaruh negative terhadap tingkat pemahaman akuntansi. Berdasarkan inkonsistensi hasil riset terdahulu, patut diduga ada faktor-faktor lain (variabel kontingensi) yang dapat memperkuat ataupun memperlemah pengaruh minat belajar terhadap tingkat pemahaman akuntansi, dua di antaranya adalah persepsi kegunaan dan persepsi kemudahan media pembelajaran OASE Udayana.

Persepsi kegunaan dan kemudahan media pembelajaran sangat menentukan dalam meningkatkan pengaruh minat belajar terhadap tingkat pemahaman akuntansi mahasiswa. Apalagi di tengah pandemi Covid-19 yang sedang melanda Indonesia serta seluruh dunia, menyebabkan proses perkuliahan yang semula dilaksanakan secara luring melalui tatap muka di kelas, kini harus dilakukan secara virtual (daring). Hal ini turut menimbulkan permasalahan baru bagi mahasiswa khususnya mahasiswa Program Studi Akuntansi, Fakultas Ekonomi dan Bisnis Universitas Udayana, dalam memahami materi yang diberikan oleh dosen. Pihak Universitas Udayana sebenarnya telah lama memiliki fasilitas media pembelajaran daring bernama OASE Udayana bahkan sebelum terjadinya pandemic. Akan tetapi pemanfaatan OASE baru dilaksanakan secara optimal pada saat pandemic Covid-19 berlangsung. Persepsi kegunaan dan kemudahan pengguna OASE salah satunya mahasiswa akan menentukan seberapa tinggi minat belajar mahasiswa tersebut dapat memengaruhi tingkat pemahaman akuntansinya.

Penelitian (Tsani, 2011) menemukan bahwa persepsi kegunaan dan kemudahan berpengaruh signifikan baik secara parsial maupun simultan terhadap prestasi belajar sebagai ukuran tingkat pemahaman siswa di SMA Negeri 1 Kramat. Berdasarkan hasil tersebut, patut diduda bahwa variabel moderasi persepsi kegunaan dan kemudahan dapat memperkuat pengaruh minat belajar terhadap tingkat pemahaman akuntansi mahasiswa. Penelitian ini berbeda dengan penelitian yang dilakukan oleh (Tsani, 2011) dimana variabel persepsi kegunaan dan kemudahan dalam penelitian ini merupakan variabel moderasi sementara pada penelitian (Tsani, 2011) sebagai variabel bebas. Penelitian ini juga berbeda di variabel moderasinya (persepsi kegunaan dan kemudahan) dengan penelitian Atmaja et al., (2017) (kecerdasan emosional dan spiritual), walaupun sama - sama meneliti minat belajar pada tingkat pemahaman akuntansi mahasiswa.

Melalui hasil penelitian ini diperoleh bukti empiris yang dapat mengonfirmasi teori terkait pengaruh positif minat belajar terhadap tingkat pemhaman akuntansi, sekaligus mengonfirmasi keterlibatan variable persepsi kegunaan dan kemudahan pada pengaruh minat belajar terhadap tingkat pemahaman akuntansi yang tidak selalu linear. Selain itu, penelitian ini nantinya juga akan menambah bukti empiris untuk memberikan masukan praktis kepada Fakultas Ekonomi dan Bisnis dan juga Universitas Udayana untuk semakin menyempurnakan aplikasi OASE Udayana, sehingga nantinya bisa menjadi media pembelajaran berbasis online yang mampu menigkatkan kualitas lulusan di Universitas Udayana. Grand theory yang digunakan pada penelitian ini adalah Taksonomi Bloom yang terkait dengan tingkat pemahaman seseorang. Selain teori 
utama, terdapat teori pendukung seperti Teori Perliaku Terencana (Theory of Planned Behaviour) oleh (Fishbein \& Ajzen, 1991) terkait minat belajar, dan teori terkait penerimaan teknologi informasi yang sering disebut dengan Technology Acceptance Model (TAM) oleh (Davis, 1989).

Teori ini dikemukakan oleh Benjamin S. Bloom, seorang psikolog bidang pendidikan, pada tahun 1956. Taksonomi ini mengklasifikasikan sasaran atau tujuan pendidikan menjadi tiga domain (ranah kawasan): kognitif, afektif, dan psikomotor dan setiap ranah tersebut dibagi kembali ke dalam pembagian yang lebih rinci berdasarkan hierarkinya (Winkel, 1983). Beberapa istilah lain yang juga meggambarkan hal yang sama dengan ketiga domain tersebut yang secara konvensional telah lama dikenal taksonomi tujuan pendidikan yang terdiri atas aspek cipta, rasa, dan karsa (Idris \& Jamal, 1992). Selain itu, juga dikenal istilah penalaran, penghayatan dan pengamalan.

Minat belajar terdiri dari dua kata yakni minat dan belajar. Dua kata ini beda arti, untuk itu penulis akan mendefinisikan satu persatu, Secara etimologi dalam Kamus Umum Bahasa Indonesia, minat diartikan sebagai "perhatian", kesukaan (kecenderungan) kepada sesuatu keinginan. Ditinjau dari segi terminologi, para ahli memberikan pendapat tentang minat, di antaranya Menurut (Ramayulis, 2001) minat adalah suatu keadaan dimana seseorang mempunyai perhatian terhadap sesuatu dan disertai dengan keinginan untuk mengetahui dan mempelajarinya maupun membuktikannya. Selain itu, menurut (Daryanto, 2010), minat adalah kecenderungan yang tetap untuk memperhatikan dan mengenang beberapa kegiatan). Melihat dari beberapa pengertian di atas yang dimaksud dengan minat adalah suatu kecenderungan dan keinginan yang besar terhadap sesuatu yang disertai dengan perasaan senang, tertarik, pemusatan perhatian, serta kecenderungan-kecenderungan yang lain yang mengarah pada suatu pilihan. (Fishbein \& Ajzen, 1991) mengemukakan tentang Teori Perilaku Terencana (Theory Of Planned Behavior). Dalam teori ini dijelaskan bahwa TPB membantu kita untuk memahami bagaimana merubah tingkah laku seseorang yang dapat dibentuk dan direncanakan.

Berdasarkan paparan Teori Perilaku Terencana dapat disimpulkan bahwa ketika adanya perpaduan ketiga faktor tersebut akan menghasilkan intensi perilaku atau minat seseorang (behavior intention). Kaitan teori tersebut dengan penelitian ini yaitu, Bahwa mahasiswa akan berniat untuk menampilkan suatu perilaku tertentu dalam hal ini minat belajar mata kuliah akuntansi, ketika dia menilainya secara positif. Sikap ini ditentukan oleh kepercayaan individu mengenai konsekuensi dari menampilkan suatu perilaku (behavioral beliefs), ditimbang berdasarkan hasil evaluasi terhadap konsekuensinya (outcome evaluation). Minat beajar mahasiswa akan muncul ketika mempersepsikan bahwa orang lain yang penting berpikir bahwa ia seharusnya melakukan hal tersebut, misalnya saja mahasiswa tersebut berniat untuk belajar akuntansi karena orang tuanya menganggap bahwa belajar akuntansi memang sebuah kewajiban bagi mahasiswa akuntansi. Minat belajar akuntansi mahasiswa akan timbul jika ada keyakinan tentang adanya faktor yang mendukung maupun menghambat perilaku dan kesadaran akan kekuatan faktor tersebut. Perpaduan ketiga hal ini yang nantinya akan menentukan tinggi rendahnya minat belajar mahasiswa 
dalam memahami mata kuliah akuntansi yang diberikan selama proses perkuliahan di kampus.

$\mathrm{H}_{1}$ : Minat belajar berpengaruh terhadap tingkat pemahaman akuntansi.

Penelitian terdahulu yang meneliti pengaruh minat belajar terhadap tingkat pemahaman masih inkonsisten. (Fanikmah \& Kurnia, 2016) menyebutkan di hasil penelitiannya bahwa minat belajar berpengaruh positif dan signifikan terhadap tingkat pemahaman akuntansi. Hasil ini juga ditemukan pada penelitian lainnya yaitu (Susanti et al., 2017), (Rokhana \& Sutrisno, 2016), dan (Atmaja et al., 2017). Berbeda dengan tiga peneliti sebelumnya penelitian (Adeviana, 2018) menemukan hasil bahwa minat belajar berpengaruh negatif terhadap tingkat pemahaman siswa. Hasil riset terbaru dari (Adeviana, 2018) juga mendukung hasil riset sebelumnya yang dilakukan (Minarni et al., 2014), yang menemukan bahwa minat belajar memiliki pengaruh negative terhadap tingkat pemahaman akuntansi. Berdasarkan inkonsistensi hasil riset terdahulu, patut diduga ada faktor-faktor lain (variabel kontingensi) yang dapat memperkuat ataupun memperlemah pengaruh minat belajar terhadap tingkat pemahaman akuntansi, dua di antaranya adalah persepsi kegunaan dan persepsi kemudahan media pembelajaran OASE Udayana

Teori Technology Acceptance Model (TAM) diadopsi dari model The Theory of Reasoned Action (TRA), yaitu teori tindakan yang dikembangkan oleh Fishbein dan (Fishbein \& Ajzen, 1991), dengan satu premis bahwa reaksi dan persepsi seseorang terhadap sesuatu hal, akan menentukan sikap dan perilaku orang tersebut. Teori ini membuat model perilaku seseorang sebagai suatu fungsi dari tujuan perilaku. Tujuan perilaku ditentukan oleh sikap atas perilaku tersebut. Teori TAM yang dikembangkan oleh Davies menitikberatkan pada suatu model digunakan untuk memperkirakan dan menjelaskan bagaimana pengguna teknologi atau user menerima dan menggunakan teknologi tersebut dalam pekerjaan atau kehidupan sehari-harinya. Dengan demikian, melalui teori ini dapat diprediksi reaksi dan persepsi pengguna (mahasiswa) media pembelajaran daring OASE Udayana. Ada tiga faktor yang mempengaruhi penggunaan sebuah sistem sesuai yang diusulkan oleh Fred Davis, yaitu persepsi kegunaan pengguna, persepsi kemudahan pengguna dan intensi penggunaan, akan tetapi pada penelitian ini menggunakan dua dari tiga faktor tersebut yaitu persepsi kegunaan dan kemudahan pengguna.

(Jogiyanto, 2017;114) mengemukakan bahwa kegunaan persepsian (perceived usefulness) didefinisikan sebagai sejauh mana seseorang percaya bahwa menggunakan suatu teknologi akan meningkatkan kinerja pekerjaannya (as the extent to which a person believes that using a technology will enhance her or his performance). Berdasarkan definisinya, diketahui bahwa kegunaan persepsian (perceived usefulness) merupakan suatu kepercayaan (belief) tentang proses pengambilan keputusan. Dengan demikian jika seseorang merasa percaya bahwa sistem informasi berguna maka dia akan menggunakannya. Sebaliknya jika seseorang merasa bahwa sistem informasi kurang berguna maka dia tidak akan menggunakannya.

Penelitian-penelitian sebelumnya menunjukkan bahwa konstruk kegunaan persepsian (perceived usefulness) mempengaruhi secara positif dan signifikan terhadap penggunaan sistem informasi misalnya (Davis, 1989), (Chau, 
1996), Sun, 2003. Penelitian (Tsani, 2011) menemukan bahwa persepsi kegunaan (perceived usefulness) berpengaruh terhadap tingkat pemahaman akuntansi. Penelitian (Tsani, 2011) dilakukan pada siswa SMA Negeri 1 Kramat. Penelitianpenelitian sebelumnya juga menunjukkan bahwa kegunaan persepsian (perceived usefulness) merupakan konstruk yang paling banyak signifikan dan penting yang mempengaruhi sikap (attitude), minat (behavioral intention), dan perilaku (behavior) di dalam menggunakan teknologi dibandingkan dengan konstruk kemudahan penggunaan persepsian (perceived ease of use). Konstruk kegunaan persepsian (perceived usefulness) dibentuk dari banyak item. Davis (1989) menggunakan 6 buah item untuk membentuk konstruk ini. Keenam item ini adalah work more quickly, job performance, increase productivity, effectiveness, makes job easier, dan useful.

Persepsi mahasiswa mengenai kegunaan media OASE Udayana didefinisikan sebagai anggapan mahasiswa bahwa media OASE Udayana berguna untuk diterapkan pada pembelajaran daring. Apabila mahasiswa percaya bahwa media OASE Udayana berguna untuk diterapkan pada pembelajaran akuntansi, maka mereka akan menggunakan media OASE Udayana untuk belajar mata kuliah akuntansi. Sebaliknya apabila mahasiswa percaya bahwa media OASE Udayana kurang berguna untuk diterapkan pada pembelajaran akuntansi, maka mereka tidak akan menggunakan media OASE Udayana untuk belajar mata kuliah akuntansi. Indikator persepsi mahasiswa mengenai kegunaan media OASE Udayana diadaptasi dari (Davis, 1989) serta (Gardner \& Amoroso, 2004) disesuaikan dengan Taksonomi Bloom yaitu kecepatan menyelesaikan tugas, pencapaian pemahaman, peningkatan partisipasi, efektivitas belajar, kemudahan mengerjakan tugas, dan kegunaan. Persepsi kegunaan media pembelajaran Oase Udayana yang tinggi akan memperkuat ataupun memperlemah pengaruh minat belajar mahasiswa Program Studi Akuntansi FEB Unud terhadap tingkat pemahaman akuntansinya.

$\mathrm{H}_{2}$ : Persepsi kegunaan memoderasi pengaruh minat belajar pada tingkat pemahaman akuntansi.

Kemudahan penggunaan persepsian (perceived ease of use), didefinisikan sebagai sejauh mana seseorang percaya bahwa menggunakan suatu teknologi akan bebas dari usaha (is the extent to which a person believes that using a technology will be free of effort). Berdasarkan definisinya, diketahui bahwa konstruk kemudahan penggunaan persepsian (perceived ease of use) ini juga merupakan suatu kepercayaan (belief) tentang proses pengambilan keputusan. Jika seseorang merasa percaya bahwa sistem informasi mudah digunakan maka dia akan menggunakannya. Sebaliknya jika seseorang merasa percaya bahwa sistem informasi tidak mudah digunakan maka dia tidak akan menggunakannya.

Hasil penelitian terdahulu yang diperoleh oleh (Tsani, 2011) menemukan bahwa persepsi kemudahan berpengaruh signifikan terhadap tingkat pemahaman akuntansi siswa. Persepsi mahasiswa terkait kemudahan penggunaan media media OASE Udayana didefinisikan sebagai anggapan mahasiswa bahwa media media OASE Udayana mudah untuk dioperasikan. Apabila mahasiswa percaya bahwa media OASE Udayana mudah untuk digunakan, maka mereka akan menggunakan media OASE Udayana untuk belajar mata kuliah akuntansinya. Sebaliknya apabila mahasiswa percaya bahwa media media OASE Udayana tidak mudah untuk digunakan, maka mereka tidak akan menggunakan media OASE 
Udayana untuk mempelajari mata kuliah akuntansinya. Indikator dari persepsi siswa mengenai kemudahan penggunaan media OASE Udayana diadaptasi dari (Davis, 1989) serta (Gardner \& Amoroso, 2004) disesuaikan dengan Taksonomi Bloom yaitu kemudahan mempelajari, dapat dikendalikan, jelas dan dapat dimengerti, fleksibel, kemahiran, serta kemudahan penggunaan. Tinggi rendahnya persepsi kemudahan pengguna OASE Udayana akan memperkuat atau memperlemah minat belajar mahasiswa terhadap tingkat pemahaman akuntansinya.

$\mathrm{H}_{3}$ : Persepsi kemudahan memoderasi pengaruh minat belajar pada tingkat pemahaman akuntansi.

Kerangka konseptual merupakan konseptual tentang bagaimana teori berhubungan dengan berbagai faktor yang telah diidentifikasikan sebagai masalah penelitian dan mendefinisikan relevansi antara variabel independen dengan dependen sesuai dengan teori yang digunakan. Penelitian ini membahas tentang moderasi persepsi kegunaan dan kemudahan OASE Udayana pada pengaruh minat belajar terhadap tingkat pemahaman akuntansi mahasiswa.

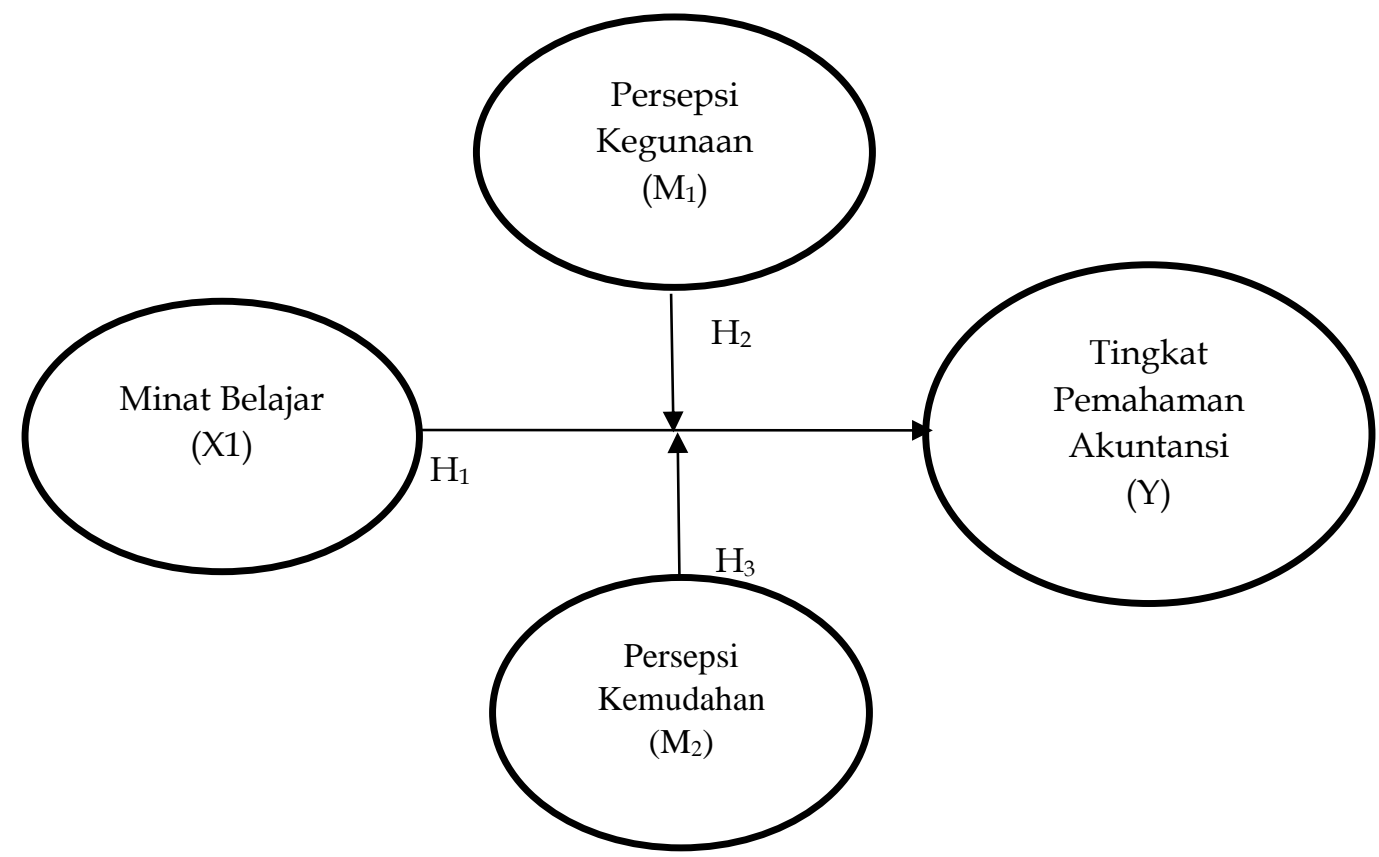

Sumber: Data Penelitian, 2020

Gambar 1. Kerangka Konseptual

\section{METODE PENELITIAN}

Populasi dalam penelitian ini adalah seluruh mahasiswa akuntansi yang telah menempuh mata kuliah pengantar akuntansi dan menggunakan OASE Udayana dalam proses perkuliahannya. Penelitian ini menggunakan teknik non probability sampling yaitu teknik purposive sampling. Adapun penelitian kriteria-kriteria yang dijadikan sebagai sampel penelitian yaitu, Sampel merupakan mahasiswa aktif Program Studi Akuntansi Fakultas Ekonomi dan Bisnis Universitas Udayana angkatan 2018, 2019 dan 2020 (tiga angkatan) dan sampel merupakan mahasiswa Program Studi Akuntansi Fakultas Ekonomi dan Bisnis Universitas Udayana yang 
telah menempuh mata kuliah pengantar akuntansi dan perkuliahannya menggunakan media pembelajaran OASE Udayana.

Dalam penelitian ini, peneliti berusaha untuk memperoleh data yang relevan dengan menggunakan kuesioner. Kuesioner disebarkan kepada mahasiswa aktif Program Studi Akuntansi Fakultas Ekonomi dan Bisnis Universitas Udayana angkatan 2018, 2019 dan 2020 (tiga angkatan) yang telah menempuh mata kuliah pengantar akuntansi dan perkuliahannya menggunakan media pembelajaran OASE Udayana. Dengan menggunakan skala likert, jawaban pilihan responden akan diberi nilai dengan skala poin 5 sebagai skor tertinggi dan skala poin 1 untuk skala poin terendah.

Menurut Slameto (2010:57), minat adalah kecenderungan yang tetap untuk memperhatikan dan mengenang beberapa kegiatan. Kegiatan itu diminati, diperhatikan terus-menerus dengan disertai rasa senang sehingga diperoleh kepuasan. Alat ukur yang digunakan untuk mengukur variabel minat belajar $\left(\mathrm{X}_{1}\right)$ adalah dengan menggunakan kuisioner yang diadopsi dari Ariyanti dkk (2010), yang dikembangkan menjadi 4 dimensi, yaitu, perasaan senang, perhatian dalam belajar, pengetahuan, dan kesadaran.

Persepsi mahasiswa mengenai kegunaan Persepsi Kegunaan (Perceived Usefulness) $\left(\mathrm{M}_{1}\right)$ media Oase Udayana didefinisikan sebagai anggapan mahasiswa bahwa media Oase Udayana berguna untuk diterapkan pada perkuliahan pengantar akuntansi. Indikator persepsi mahasiswa mengenai kegunaan media Oase Udayana diadaptasi dari (Davis, 1989) serta (Gardner \& Amoroso, 2004) disesuaikan dengan Taksonomi Bloom yaitu, Kecepatan menyelesaikan tugas (aspek psikomotorik), Pencapaian pemahaman (aspek kognitif), Peningkatan partisipasi (aspek afektif), Efektivitas belajar (aspek kognitif), Kemudahan mengerjakan tugas (aspek psikomotorik), dan Kegunaan.

Persepsi mahasiswa mengenai kemudahan Persepsi Kemudahan (Perceived Ease of Use) $\left(\mathrm{M}_{2}\right)$ penggunaan media OASE Udayana didefinisikan sebagai anggapan mahasiswa bahwa media OASE Udayana mudah untuk digunakan atau dioperasikan. Indikator dari persepsi siswa mengenai kemudahan penggunaan media OASE Udayana diadaptasi dari (Davis, 1989) serta (Gardner \& Amoroso, 2004) disesuaikan dengan Taksonomi Bloom yaitu, Kemudahan mempelajari (aspek kognitif), Dapat dikendalikan (aspek psikomotorik), Jelas dan dapat dimengerti (aspek kognitif), Fleksibel (aspek afektif), Kemahiran (aspek psikomotorik), dan Kemudahan penggunaan.

Tingkat Pemahaman Akuntansi (Y) merupakan tingkat kemampuan seseorang untuk mengenal dan mengerti tentang akuntansi. Untuk mengukur tingkat pemahaman akuntansi menggunakan rata-rata nilai mata kuliah yang berkaitan dengan akuntansi yaitu pengantar akuntansi. Satuan pengukuran yang digunakan adalah skala rasio. Skala rasio merupakan skala pengukuran yang ditujukan kepada hasil pengukuran yang bisa dibedakan, diurutkan, mempunyai jarak tertentu dan bisa dibandingkan. Tingkat pemahaman akuntansi diukur dari nilai mata kuliah Pengantar Akuntansi mahasiswa yang tertera di Kartu Hasil Studi (KHS) mahasiswa, data didapatkan dari bagian akademik FEB Unud ataupun Infokom FEB Unud.

Selain menggunakan kuesioner, pengumpulan data dalam penelitian ini juga menggunakan teknik dokumentasi. Instrumen penelitian yang digunakan 
dalam penelitian ini yaitu, Uji Validitas, dan Uji Reliabilitas. Teknik Analisis data yang digunakan yaitu Statistik Deskriptif, Uji asumsi klasik, uji Analisis Regresi Moderasi (MRA), Uji Hipotesis (Uji t), Uji Kelayakan Model (Uji F), dan Uji Koefisien Determinasi. Dalam menguji hipotesis dikembangkan suatu persamaan untuk menyatakan hubungan antara variabel dependen, yaitu Tingkat Pemahaman Akuntansi ( $\mathrm{Y})$ dengan variabel independen, yaitu Minat Belajar $\left(\mathrm{X}_{1}\right)$, dan interaksi dengan dua variable moderasi Independensi $\left(\mathrm{M}_{1}\right)$ serta Manacika Parisudha $\left(\mathrm{M}_{2}\right)$. Pengujian hipotesis dengan analisis regresi linear berganda diformulasikan sebagai berikut.

$Y=a+b_{1} X_{1}+b_{2} M_{1}+b_{3} M_{2}+b_{4} X_{1} M_{1}+b_{5} X_{1} M_{2}+\varepsilon$

Keterangan:

$\mathrm{Y} \quad=$ Tingkat Pemahaman Akuntansi

a $\quad=$ Nilai Konstanta

$\mathrm{X}_{1} \quad=$ Minat Belajar

$\mathrm{M}_{1} \quad=$ Persepsi Kegunaan

$\mathrm{M}_{2} \quad$ = Persepsi Kemudahan

$\mathrm{b}_{1} \quad=$ Koefisien Regresi Variabel Independen

$\mathrm{b}_{2}-\mathrm{b}_{3} \quad=$ Koefisien Regresi Variable Moderasi

$\mathrm{b}_{4}-\mathrm{b}_{5} \quad=$ Koefisien regresi interaksi $\mathrm{X}_{1}$ dengan $\mathrm{M}_{1}$ dan $\mathrm{M}_{2}$

$\varepsilon \quad=$ Standar Error

\section{HASIL DAN PEMBAHASAN}

Kuesioner penelitian ini disebarkan pada mahasiswa Program Studi Akuntansi Angkatan 2018, 2019 dan 2020, dengan persyaratan telah menempuh mata kuliah pengantar akuntansi dan proses perkuliahannya menggunakan OASE. Jumlah kuesioner yang disebarkan sebanyak 100 kuesioner, namun yang kembali sebanyak 91 kuesioner, dengan tingkat konversi kuesioner sebesar 91\%. Responden yang mengisi sebagian besar berjenis kelamin perempuan dengan total 70 mahasiswa (77\%) sementara laki-laki sebanyak 21 mahasiswa $(23 \%)$, dengan rincian sebagai berikut.

Tabel 1. Jumlah Responden Per Angkatan dan Jenis Kelamin

\begin{tabular}{cccc}
\hline \multirow{2}{*}{ Angkatan } & \multirow{2}{*}{ Jumlah } & \multicolumn{2}{c}{ Jenis Kelamin } \\
\cline { 3 - 4 } & & Laki-Laki & Perempuan \\
\hline 2018 & 31 & 3 & 24 \\
2019 & 23 & 11 & 20 \\
2020 & 37 & & 26 \\
\hline
\end{tabular}

Sumber : Data Penelitian, 2018

Berdasarkan hasil uji validitas ketiga variabel yaitu Minat Belajar $\left(\mathrm{X}_{1}\right)$, Persepsi Kegunaan $\left(\mathrm{M}_{1}\right)$, dan Persepsi Kemudahan $\left(\mathrm{M}_{2}\right)$, yang menggunakan data primer (kuesioner) sebagai sumber datanya, telah dinyatakan valid karena seluruh nilai signifikansi pearson correlation dari masing-masing variabel lebih besar dari 0,3 atau nilai signifikansinya lebih kecil dari 0,05. Berdasarkan hasil uji reliabilitas ketiga variabel yaitu Minat Belajar $\left(\mathrm{X}_{1}\right)$, Persepsi Kegunaan $\left(\mathrm{M}_{1}\right)$, dan Persepsi Kemudahan $\left(\mathrm{M}_{2}\right)$ seluruhnya dinyatakan reliable, karena memiliki nilai cronbach alpha di atas 0,6 .

Penelitian ini melakukan dua kali pengujian normalitas data, pada pengujian pertama mendapatkan nilai signifikansi sebesar $0,000<$ dari alpha 0,05 , 
artinya data berdistribusi tidak normal. Karena data berdistribusi tidak normal, maka dilakukan pengujian outlier atau data pengganggu yang harus dihilangkan dari sampel penelitian.

Deteksi terhadap outlier dapat dilakukan dengan menetukan nilai batas yang akan dikategorikan sebagai data outlier yaitu dengan cara mengkonversi nilai data ke dalam skor standardized atau yang biasa disebut z-score (Ghozali, 2013:41). Menurut Hair (1998) dalam (Ghozali, 2013:41) untuk kasus sampel kecil (kurang dari 80) maka standar skor dengan nilai $\geq 2,5$ dinyatakan outlier. Berdasarkan hasil uji outliers, ada dua belas (12) sampel yang dikategorikan data outlier sehingga harus dieliminasi dari sampel penelitian, sekaligus menyebabkan sampel berkurang dari sebelumnya berjumlah 91 data menjadi 79 .

Tabel 2. Hasil Uji Normalitas

\begin{tabular}{cc}
\hline One Sample Kolmogorov-Smirnov & Nilai Singifikansi \\
\hline Signifikansi (2-tailed) & 0,200
\end{tabular}

Sumber: Data Penelitian, 2020

Uji normalitas dengan jumlah sampel/data terbaru (79) yang dapat dilihat pada Tabel 2, menunjukan hasil nilai signifikansi One Sample - Kolmogorov Smirnov 0,200 > alpha sebesar 0,05, artinya data telah berdistribusi normal sehingga data dapat dilakukan pengujian selanjutnya. Hasil uji normalitas dapat dilihat pada Tabel 1, sebagai berikut.

Tabel 3. Uji Multikolinearitas

\begin{tabular}{lcc}
\hline Variabel & Nilai Tolerance & Nilai Signifikansi \\
\hline $\mathrm{X}_{1}$ (Minat Belajar) & 0,893 & 1,120 \\
$\mathrm{M}_{1}$ (Persepsi Kegunaan ) & 0,914 & 1,094 \\
$\mathrm{M}_{2}$ (Persepsi Kemudahan $)$ & 0,939 & 1,065 \\
\hline
\end{tabular}

Sumber: Data Penelitian, 2020

Variabel penelitian dinyatakan lolos uji multikolinearitas saat nilai VIF lebih kecil dari 10 (VIF < 10) atau nilai tolerance lebih besar dari 0,1 (tolerance $>0,1)$. Berdasarkan Tabel 3, ketiga variabel bebas memilki nilai VIF yang lebih kecil dari 10 dan nilai tolerance lebih besar dari 0,1, sehingga dapat disimpulkan, variabel penelitian telah lolos uji multikolinearitas.

Tabel 4. Uji Heteroskedastisitas

\begin{tabular}{lc}
\hline Variabel & Nilai Signifikansi \\
\hline $\mathrm{X}_{1}$ (Minat Belajar) & 0,516 \\
$\mathrm{M}_{1}$ (Persepsi Kegunaan) & 0,442 \\
$\mathrm{M}_{2}$ (Persepsi Kemudahan) & 0,086 \\
\hline
\end{tabular}

Sumber: Data Penelitian, 2020

Pengujian ini dapat dianalisis melalui uji Glesjer Test yaitu dengan meregresi nilai absolute residual model yang destimasi terhadap variabel-variabel independen dengan memperhatikan nilai t-statistik dan signifikansinya (Ghozali, 2013:105). Syarat lolos uji ini adalah nilai signifikansi di atas alpha 0,05. Berdasarkan hasil yang disajikan dalam Tabel 4, nilai signifikansi ketiga variabel bebas memiliki nilai signifikansi di atas nilai alpha $0,05(>0,05)$, hal ini berarti, seluruh variabel yang digunakan dalam penelitian telah lolos uji heteroskedastisitas.

Hasil uji hipotesis pada penelitian ini dibagi menjadi dua tahapan. Tahapan pertama adalah pengujian hipotesis untuk melihat pengaruh langsung 
variabel minat belajar terhadap tingkat pemahaman akuntansi sebelum adanya interaksi dengan variabel moderasi. Tahapan kedua adalah tahapan pengujian interaksi variabel bebas dengan variabel moderasi menggunakan teknik analisis data moderated regression analysis (MRA) untuk menjawab $\mathrm{H}_{2}$ dan $\mathrm{H}_{3}$. Kedua tahapan pengujian hipotesis memiliki kriteria penerimaan hipotesis jika nilai signifikansi $p$-value lebih kecil dibandingkan nilai alpha $(0,05)$. Hasil pengujian hipotesis sebelum interaksi moderasi disajikan pada Tabel 5.

\section{Tabel 5. Hasil Uji Hipotesis $\mathbf{H}_{1}$}

\begin{tabular}{cccc}
\hline Variabel & Nilai Koefisien Beta $(\mathrm{B})$ & Nilai Signifikansi & Keterangan \\
\hline $\mathrm{X}_{1}$ (Minat Belajar) & 0,707 & 0,000 & $\mathrm{H}_{1}$ : Diterima \\
\hline Nilai signifikansi pengaruh variabel Minat Belajar $\left(\mathrm{X}_{1}\right)$ & terhadap tingkat
\end{tabular}
pemahaman akuntansi $(Y)$ sebesar 0,000 dengan koefisien beta sebesar 0,707. Karena nilai signifikansi pengaruh variabel minat belajar lebih kecil daripada alpha $(0,000<0,05)$, maka hipotesis alternative satu $\left(\mathrm{H}_{1}\right)$ diterima, dengan kata lain minat belajar berpengaruh terhadap tingkat pemahaman akuntansi. Arah pengaruhnya adalah positif karena nilai koefisien beta variabel minat belajar bertanda positif $(0,707)$.

Pengujian hipotesis setelah adanya interaksi dengan variabel moderasi dilakukan menggunakan teknik analsisi regresi moderasi atau MRA, dan hasilnya disajikan pada Tabel 6. Pada tabel tersebut nilai signifikansi $\mathrm{X}_{1 \_} \mathrm{M}_{1}$ (interaksi variabel minat belajar dengan variabel moderasi persepsi kegunaan) adalah sebesar 0,492 dengan nilai koefisien beta sebesar 0,017. Nilai signifikansi ini lebih besar dari alpha 0,05 , hal ini berarti $\mathrm{H}_{2}$ ditolak, atau dapat dinyatakan bahwa variabel persepsi kegunaan tidak memoderasi pengaruh minat belajar terhadap tingkat pemahaman akuntansi. Nilai signifikansi $\mathrm{X}_{1 \_} \mathrm{M}_{2}$ (interaksi variabel minat belajar dengan variabel moderasi persepsi kemudahan) sebesar 0,018 dengan koefisien beta sebesar 1,153. Nilai signifikansi ini lebih kecil dari alpha 0,05, kesimpulanya $\mathrm{H}_{3}$ diterima, atau dapat dinyatakan bahwa variabel moderasi persepsi kemudahan memoderasi pengaruh minat belajar terhadap tingkat pemahaman akuntansi.

Tabel 6. Hasil Uji Hipotesis $\mathrm{H}_{2}$ dan $\mathrm{H}_{3}$

\begin{tabular}{lccc}
\hline Variabel & $\begin{array}{c}\text { Nilai Koefisien } \\
\text { Beta (B) }\end{array}$ & $\begin{array}{c}\text { Nilai } \\
\text { Signifikansi }\end{array}$ & Keterangan \\
\hline \multicolumn{1}{c}{ Konstanta } & 204,758 & & \\
$\mathrm{X}_{1}$ (Minat Belajar) & 0,371 & 0,025 & - \\
$\mathrm{M}_{1}$ (Persepsi Kegunaan) & 0,495 & 0,541 & - \\
$\mathrm{M}_{2}$ (Persepsi Kemudahan) & 5,262 & 0,019 & - \\
$\mathrm{X}_{1 \_} \mathrm{M}_{1}$ (Interaksi Minat Belajar & 0,017 & 0,492 & $\mathrm{H}_{2}$ : Ditolak \\
dengan Persepsi Kegunaan & & & \\
$\mathrm{X}_{1} \mathrm{M}_{2}$ (Interaksi Minat Belajar & 1,153 & 0,018 & $\mathrm{H}_{3}$ : \\
dengan Persepsi Kemudahan) & & & Diterima \\
$\mathrm{R}$ & $: 0,829$ & & \\
$\mathrm{R}$ Square & $: 0,688$ & & \\
$\mathrm{~F}$ & $: 32,204$ & & \\
Nilai Signifikansi & $: 0,000$ & & \\
\hline
\end{tabular}

Berdasarkan hasil uji regresi moderasi menggunakan teknik MRA, diperoleh model prediksian sebagai berikut. 


$$
\mathrm{Y}=204,758+0,371\left(\mathrm{X}_{1}\right)+0,495\left(\mathrm{M}_{1}\right)+5,262\left(\mathrm{M}_{2}\right)+0,017\left(\mathrm{X}_{1} \_\mathrm{M}_{1}\right)+1,153\left(\mathrm{X}_{1} \mathrm{M}_{2}\right)+\varepsilon
$$

Hasil uji koefisien determinasi atau $R$ Square dapat dilihat pada Tabel 6. Pada Tabel 6, nilai koefisien determinasi sebesar 0,688 , atau $68,8 \%$, artinya variabel bebas yang digunakan dalam model penelitian dapat menjelaskan perubahan atau variasi variabel terikat sebesar $68,8 \%$, sementara sisanya $(31,2 \%)$ dipengaruhi oleh variabel lain di luar model. Pada Tabel 6, juga ditampilkan hasil uji koefisien korelasi sebesar 0,829, artinya antara variabel bebas dengan variabel terikat dalam penelitian ini memiliki hubungan yang kuat. Tabel 6, menyajikan hasil Uji F atau hasil uji kelayakan model. Dari hasil pengujian didapatkan nilai signifikansi sebesar 0,000 lebih kecil dari alpha 0,05. Ini berarti secara simultan atau serempak, variabel $X_{1}, M_{1}, M_{2}, X_{1} M_{1}$, dan $X_{1} \_M_{2}$ berpengaruh terhadap variabel $Y$, atau dapat pula dinyatakan bahwa, model yang digunakan dalam penelitian ini telah layak/baik. Minat belajar secara statistik berpengaruh positif dan signifikan terhadap tingkat pemahaman akuntansi, menurut hasil uji hipotesis $\mathrm{H}_{1}$ artinya, semakin baik/tinggi minat seorang mahasiswa dalam belajar, maka akan berdampak pada peningkatan pemahaman akuntansinya. Sebaliknya, semakin rendah minat belajar mahasiswa, maka tingkat pemahaman akuntansinya juga akan semakin rendah.

Jika dikaitkan dengan Teori Bloom, tujuan pendidikan terbagi ke dalam tiga domain yaitu kognitif, afektif, dan psikomotor dan setiap ranah tersebut dibagi kembali ke dalam pembagian yang lebih rinci berdasarkan hierarkinya (Wingkel, 1987). Ketika mahasiswa memiliki minat belajar yang baik/tinggi, artinya ia memiliki keinginan untuk tidak hanya mengetahui materi akuntansi (ranah kognitif), tetapi juga memahami dan menerapkan perilaku layaknya seorang akuntan (ranah afektif) hingga terampil dalam praktek-praktek yang ada pada ilmu-ilmu akuntansi (ranah psikomotorik), sehingga dengan minat belajar yang tinggi tersebut, mahasiswa akan mampu meningkatkan tingkat pemahaman akuntansinya. Hasil penelitian ini mendukung hasil penelitian sebelumnya oleh (Fanikmah \& Kurnia, 2016), (Susanti et al., 2017), (Rokhana \& Sutrisno, 2016), dan (Atmaja et al., 2017) yang menemukan hasil serupa yaitu minat belajar berpengaruh terhadap tingkat pemahaman dalam hal ini tingkat pemahaman pada ilmu akuntansi.

Persepsi kegunaan secara statistic tidak memoderasi pengaruh minat belajar pada tingkat pemahaman akuntansi. Hal ini sekaligus menolak hipotesis alternative dua $\left(\mathrm{H}_{2}\right)$, yang berarti variabel persepsi kegunaan dari media pembelajaran daring OASE Universitas Udayana tidak mampu memperkuat ataupun memperlemah pengaruh minat belajar terhadap tingkat pemahaman akuntansi.

Menurut Teori Technology Acceptance Model (TAM), persepsi kegunaan pengguna sebuah teknologi adalah ketika pengguna merasakan manfaat dari penggunaan teknologi tersebut dalam pekerajaan sehari-harinya. Jika dikaitkan dengan penelitian ini maka dapat disimpulkan bahwa, mahasiswa masih mempersepsikan bahwa media pembelajaran daring OASE Universitas Udayana belum bermanfaat secara maksimal dalam menunjang perkuliahan khususnya saat menempuh mata kuliah pengantar akuntansi. Hal ini juga berarti, minat belajar mahasiswa yang tinggi akan disalurkan ke media pembelajaran daring yang lain, atau bahkan media pembelajaran luring. 
Selama masa pandemi Covid-19, sebagian besar dosen-dosen di lingkungan Fakultas Ekonomi dan Bisnis Universitas Udayana sudah mencoba menggunakan OASE Universitas Udayana sebagai salah satu media pembelajaran daring khususnya dalam mata kuliah akuntansi, akan tetapi tidak sedikit pula yang belum menggunakan aplikasi tersebut. Bagi dosen-dosen yang telah menggunakan OASE, penggunaannya juga belum secara maksimal, sehingga mahasiswa belum merasakan manfaat OASE sebagai tempat untuk menambah pemahaman akuntansinya selain tatap muka dengan dosen melalui Webex Meeting/Zoom Meeting.

Hasil ini berbeda dari hasil penelitian (Tsani, 2011) yang menemukan bahwa persepsi kegunaan (perceived usefulness) berpengaruh terhadap tingkat pemahaman akuntansi. Sementara, hasil ini sejalan dengan hasil penelitian (Tyas \& Darma, 2017) yang menyatakan bahwa persepsi kegunaan tidak berpengaruh secara signifikan terhadap penerimaan teknologi informasi. Ketika sebuah teknologi yang diperkenalkan kepada pengguna (dalam hal ini media OASE yang digunakan oleh mahasiswa) dipersepsikan kurang bermanfaat, akan berdampak pada tidak diterimanya teknologi informasi tersebut, padahal untuk memahami materi kuliah akuntansi, tidak cukup hanya mendengarkan penjelasan dosen saat tatap muka, tetapi perlu materi tambahan dan latihan dalam menjawab kasuskasus akuntansi untuk meningkatkan pemahaman akuntasi mahasiswa, yang seluruh sebenarnya bisa dilakukan pada OASE Universitas Udayana.

Persepsi kemudahan secara statistik memoderasi pengaruh minat belajar pada tingkat pemahaman akuntansi. Hal ini sekaligus menerima hipotesis alternative tiga $\left(\mathrm{H}_{3}\right)$. Nilai koefisien beta interaksi moderasi antara minat belajar dan persepsi kemudahan juga bertanda positif, yang berarti variabel persepsi kemudahan dari media pembelajaran daring OASE Universitas Udayana mampu memperkuat pengaruh minat belajar terhadap tingkat pemahaman akuntansi mahasiswa.

Berdasarkan teori TAM, ketika sebuah teknologi dipersepsikan mudah digunakan, artinya pengguna (user) dalam hal ini mahasiswa akan memilih untuk menerima dan menggunakan teknologi tersebut (OASE) demi menunjang kegiatan perkuliahan sehari-hari. Minat belajar mahasiswa yang tinggi diperkuat dengan kemudahan penggunaan media pembelajaran daring OASE, tentu akan semakin meningkatkan pemahaman akuntansinya. Hasil penelitian ini mendukung hasil penelitian terdahulu yang diperoleh oleh (Tsani, 2011) yang menemukan bahwa, persepsi kemudahan berpengaruh signifikan terhadap tingkat pemahaman akuntansi.

\section{SIMPULAN}

Berdasarkan pembahasan hasil dapat disimpulkan bahwa Minat belajar mahasiswa berpengaruh terhadap tingkat pemahaman akuntansinya. Arah pengaruh minat belajar adalah positif dilihat dari koefisien betanya. Minat belajar mahasiswa Prodi S1 Akuntansi FEB Unud pada masa pandemic relatif baik, sehingga hal tersebut menyebabkan tingkat pemahaman akuntansinya juga baik. Persepsi kegunaan tidak memoderasi pengaruh minat belajar pada tingkat pemahaman akuntansi. Persepsi kegunaan tidak memperkuat ataupun memperlemah pengaruh minat belajar terhadap tingkat pemahaman 
akuntansinya, hal ini salah satunya disebabkan belum dirasakannya manfaat OASE Universitas Udayana secara maksimal oleh mahasiswa. Hal ini kemungkinan disebabkan oleh pemanfaatan OASE yang belum maksimal oleh dosen-dosen di lingkungan Prodi S1 Akuntansi FEB Unud. Persepsi kemudahan memoderasi pengaruh minat belajar pada tingkat pemahaman akuntansi. Arah pengaruhnya positif, artinya persepsi kemudahan memperkuat pengaruh minat belajar pada tingkat pemahaman akuntansinya. Minat belajar yang tinggi dimiliki mahasiswa S1 Akuntansi FEB Unud, diperkuat dengan mudahnya penggunaan OASE Universitas Udayana, sehingga memudahkan mahasiswa dalam mengakses materi maupun latihan kasus tambahan yang diberikan oleh dosen di kelas. Hal ini tentu berdampak pada peningkatan tingkat pemahaman akuntansi mahasiswa tersebut.

Fakultas Ekonomi dan Bisnis khususnya Prodi S1 Akuntansi perlu mengadakan pelatihan/penyegaran kembali penggunaan OASE Universitas Udayana kepada dosen-dosen di lingkungan Prodi S1 Akuntansi. Dekan beserta jajaran serta koprodi diharapkan dapat mendorong penggunaan OASE sebagai media pembelajaran daring di era pandemic Covid-19, baik untuk dosen maupun mahasiswa, sehingga materi-materi yang tidak dapat secara penuh dijelaskan saat perkuliahan tatap muka melalui aplikasi Webex/Zoom, dapat dipelajari oleh mahasiswa melalui OASE disaat perkuliahan telah berakhir. Pemberian insentif bagi dosen yang menggunakan OASE secara penuh dalam mendukung perkuliahan sehari-hari. Menyusun, mengunggah, dan membuat materi tentu saja memerlukan waktu yang tidak sedikit, apalagi jika dalam satu semester dosen tidak hanya dibebani oleh tugas di bidang pendidikan/pengajaran saja, tetapi juga penelitian dan pengabdian. Untuk itu, dirasa perlu meningkatkan insentif bagi dosen yang menggunakan OASE di saat perhitungan remunerasi. Pemberian ini sebagai bentuk hadiah, semangat dan komitmen Universitas bagi dosen-dosen yang berkinerja lebih tinggi di bidang pengajaran. Perlunya maintenance/perawatan website secara berkala oleh USDI Unud, karena aplikasi OASE sering mengalami kendala teknis seperti tidak dapat diakses oleh dosen maupun mahasiswa saat perkuliahan, UTS, maupun UAS.

\section{REFERENSI}

Adeviana, R. (2018). Pengaruh Tingkat Pendapatan Orang Tua, Persepsi Fasilitas Belajar, Dan Minat Belajar Terhadap Hasil Belajar Pada Mata Pelajaran Ekonomi Siswa Kelas XI SMA Negeri 16 Surabaya. Jurnal Pendidikan Ekonomi (JUPE), 6(3), 150-156. https://doi.org/10.26740/jupe.v6n3.p\%p

Atmaja, R., Ramantha, I. W., \& Suartana, I. W. (2017). Pengaruh Minat Belajar Pada Pemahaman Akuntansi Dengan Kecerdasan Emosional Dan Kecerdasan Spiritual Sebagai Pemoderasi. E-Jurnal Ekonomi Dan Bisnis Universitas Udayana, 6(5), 2021-2046. https://ojs.unud.ac.id/index.php/EEB/article/view/29302

Budhiyanto, J., S., \& I. N., P. (2004). Pengaruh Kecerdasan Emosional terhadap Tingkat Pemahaman Akuntansi. Jurnal Ekonomi Bisnis, X(2), 260-281.

Chau, P. Y. K. (1996). An Empirical Assessment of a Modified Technology Acceptance Model. Journal of Management Information Systems, 13(2), 185-204. https://doi.org/10.1080/07421222.1996.11518128 
Daryanto. (2010). Belajar dan Mengajar. Bandung: CV Yrama Widya.

Davis, F. (1989). Perceived Usefulness, Perceived Ease of Use, and User Acceptance of Information Technology. MIS Quarterly, 13(3), 319-340. https://doi.org/10.2307/249008

Fanikmah, D. A., \& Kurnia. (2016). Pengaruh Kecerdasan Emosional Dan Minat Belajar Terhadap Tingkat Pemahaman Akuntansi. Jurnal Ilmu Dan Riset Akuntansi, $5(7)$, $1-17$. http://jurnalmahasiswa.stiesia.ac.id/index.php/jira/article/view/1847

Fishbein, M., \& Ajzen, I. (1991). The Influence of Attitudes on Behavior. The Handbook of Attitudes.

Gardner, C., \& Amoroso, D. L. (2004). Development of an Instrument to Measure the Acceptance of Internet Technology by Consumers. Proceedings of the 37th Hawaii International Conference on System Sciences, 1-10.

Ghozali, I. (2013). Aplikasi Analisis Multivariate Dengan Program IBM SPSS 21 (Edisi Tujuh). Badan Penerbit Universitas Diponegoro.

Horngren, C. T., Datar, S. M., \& Rajan, M. V. (2011). Cost Accounting: A Managerial Emphasis. In Fourteenth Edition. Pearson Education Inc.

Idris, Z., \& Jamal, L. (1992). Pengantar Pendidikan I. Jakarta: Grasindo.

Jogiyanto. (2017). Sistem Informasi Keprilakuan. Yogyakarta: Andy.

Minarni, Buwono, S., \& Okianna. (2014). Minat Belajar Terhadap Hasil Belajar Siswa Pada Pembelajaran Akuntansi Di Kelas XI IPS. Jurnal Pendidikan Dan Pembelajaran Khatulistiwa, $3(7)$. https://jurnal.untan.ac.id/index.php/jpdpb/article/view/6432

Praptiningsih, A., Soeryati, \& Sidharta, E. A. (2009). Hubungan Keefektifan Guru Dalam Mengajar Dan Motivasi Berprestasi Siswa Dengan Prestasi Belajar Siswa Pada Bidang Studi Akuntansi (studi pada SMA Ardjuna Malang) [Universitas Negeri Malang. Program Studi Akuntansi]. http:/ / mulok.library.um.ac.id/home.php?s_data=Skripsi\&s_field=0\&mod= b\&cat $=3 \&$ id $=32954$

Ramayulis. (2001). Metodologi Pengajaran Agama Islam. Jakarta: Kalam Mulia.

Rokhana, L. A., \& Sutrisno, S. (2016). Pengaruh Kecerdasan Emosional, Perilaku Belajar, Dan Minat Belajar Terhadap Tingkat Pemahaman Akuntansi. (Studi Empiris Pada Mahasiswa Akuntansi Fakultas Ekonomika Dan Bisnis UNTAG Semarang). Media Ekonomi Dan Manajemen, 31(1). http://jurnal.untagsmg.ac.id/index.php/fe/article/view/282

Slameto. (2003). Belajar dan Faktor-faktor Yang Mempengaruhinya. Jakarta: Rineka Cipta.

Susanti, S., Rispantyo, \& Kristianto, D. (2017). Pengaruh Minat Belajar, Perilaku Belajar, Kecerdasan Intelektual Dan Kecerdasan Emosional Terhadap Tingkat Pemahaman Akuntansi. Akuntansi Dan Sistem Teknologi Informasi, 13. https://ejurnal.unisri.ac.id/index.php/Akuntansi/article/view/1620

Syah. (2003). Psikologi Belajar. Jakarta: PT Raja Grafindo.

Tsani, S. F. (2011). Sepsi Siswa Mengenai Kegunaan Dan Kemudahan Penggunaan Media Account Board, Serta Pengaruhnya Terhadap Hasil Belajar Jurnal Penyesuaian Pada SMA Negeri 1 Kramat [Universitas Negeri Semarang]. http://lib.unnes.ac.id/8039/1/10552.pdf

Tyas, E. I., \& Darma, E. S. (2017). Pengaruh Perceived Usefulness, Perceived Ease 
of Use, Perceived Enjoyment, dan Actual Usage Terhadap Penerimaan Teknologi Informasi: Studi Empiris Pada Karyawan Bagian Akuntansi dan Keuangan Baitul Maal Wa Tamwil Wilayah Daerah Istimewa Yogyakarta dan Sek. Reviu Akuntansi Dan Bisnis Indonesia, 1(1), 25-35. https://journal.umy.ac.id/index.php/rab/article/view/7658

Winkel, W. . (1983). Psikologi Pengajaran. Jakarta: PT. Gramedia Widia Sarana Indonesia. 